This full text version, available on TeesRep, is the PDF (final version) of:

Crosby, C. (2010) 'Culpability, Kingston and the law commission', Journal of Criminal Law, 74 (5), pp.434-468.

For details regarding the final published version please click on the following link:

http://www.rjerrard.co.uk/law/jcl/jcllatest.htm

When citing this source, please use the final published version as above.

This document was downloaded from http://tees.openrepository.com/tees/handle/10149/114673 Please do not use this version for citation purposes.

All items in TeesRep are protected by copyright, with all rights reserved, unless otherwise indicated. 
Journal of Criminal Law/2010, Volume 74/Issue 5, October/Articles/Culpability, Kingston and the Law Commission - JoCL 74 (434)

Journal of Criminal Law

JoCL 74 (434)

1 October 2010

\title{
Culpability, Kingston and the Law Commission
}

\author{
Culpability, Kingston and the Law Commission
}

Cath Crosby 1

Senior Lecturer, Teesside University; e-mail: C.Crosby@tees.ac.uk.
(C) Vathek Publishing, 2010

\begin{abstract}
This article considers the basis upon which a person should be held to be criminally liable, and to do so, it is necessary to examine the leading theories of character and choice that underpin the State holding a person to be culpable of a criminal offence, i.e. the link between culpability and fault. The case of $R v$ Kingston2 is used to examine the application of these leading theories and it is observed that choice theorists would not excuse such a defendant from criminal liability even though his capacity to make a choice to refrain from law breaking was made extremely difficult by external factors beyond his control. Only character theory could possibly offer exculpation in such circumstances on the basis that the defendant acted 'out of character' and his deed did not deserve the full censure and punishment of the criminal law. The Court of Appeal in $R v$ Kingston would have been prepared to excuse, but the House of Lords, and most recently the Law Commission have adopted a pragmatic approach to the involuntarily intoxicated offender. This case serves as a reminder that while justice is the aim of the criminal justice system, it is not an absolute standard.
\end{abstract}

Keywords Culpability; Choice; Character; Intoxication; $R$ v Kingston

Culpability is often referred to as a requirement for moral blameworthiness, but there is uncertainty as to what is meant by the use of the word 'moral' in this context. Although traditionally there were few criminal offences and all were easily recognisable as morally wrongful conduct in themselves, for example rape, murder and theft, the number of criminal offences now exceeds $8,000^{3}$ and most of these are regulatory offences, ${ }^{4}$ which are often morally neutral. From this it would appear that criminal culpability can now arise without conduct being judged as morally wrongful per se and without requiring moral blameworthiness to be shown even for more serious offences. ${ }^{5}$ This stance has been a fairly recent legal development as in 1990 it was acknowledged that:

while utilitarian theorists do not insist on any necessary link between criminal liability and moral culpability, they do assume that the law's moral responsibility requirement will reassure the public that the criminal actor deserves moral blame when he is convicted of a serious non-regulatory offense. 6

Three general theories of blame and excuses have been identified 7 which have been attributed mainly to Bentham, ${ }^{8}$ Kant $^{9}$ and Hume. ${ }^{10}$ Bentham's utilitarian rationale for excuses was that punishment of the individual by the State would not act as a deterrent in the circumstances where the excuses are allowed. For example, when acting under duress, the threat of criminal liability is subsumed by considerations that are temporarily more important to the actor. This approach has been rejected by some ${ }^{11}$ upon the ground that punishment can act as a general deterrence rather than at an individual level. Kant ${ }^{12}$ also rejected any form of utilitarian theory as it conflicted with his own theory founded on the rights of the individual. ${ }^{13}$ As such, any 
approach based upon the greatest happiness of the greatest number has to be dismissed no matter how much overall good Bentham's theory would produce. Judicial punishment could never be justified solely as a way of advancing some other good for the criminal himself or for society at large, but only on the basis that a person had committed a crime.

He must be deserving of punishment before any consideration is given to the utility of this punishment for himself or his fellow citizens. The law concerning punishment is a categorical imperative, and woe to him who rummages around in the winding path of a theory of happiness ... in keeping with the Pharisaic motto 'It is better that one man should die than that the whole people should perish'. ${ }^{14}$

\section{Two leading theories of culpability}

The modern predominant theories are based upon Kantian theory: that people should not be punished if they could not have avoided doing a criminal act; and Humean ${ }^{15}$ or Aristotelian theory, ${ }^{16}$ based upon the character traits of the individual. These are the two main theories of excuses or culpability which claim to establish the proper basis of criminal liability. They are both deemed to be subjective in nature in that they do not focus on the actual impact of someone's actions upon the world, but instead focus either on the individual choices a person makes or alternatively on a person's character. However, character theory is to an extent objective in that good/bad character is judged against an external objective standard of what can be expected from a reasonable person, whereas choice is focused on the individual's reason and belief.

\section{Choice theory}

'Choice' theory is an adaptation of Kantian retributivism 17 and the principle of desert underpinning justification for punishment. The essence of Kant's moral and political philosophy was the 'dignity of the individual' whereby morality and law should only be founded on the rights of individual man to autonomy. Choice is important because of the need to respect autonomy and, on Kantian principles, a person should only be criminally liable for harm that he is responsible and culpable for bringing about. It is only matters which a person has control over that he can be responsible for and it is only what he chooses to do or cause to happen that he controls. 18 This approach restricts influences of chance and luck over which we have no control and which should be irrelevant to culpability and criminal liability. ${ }^{19}$ On Kant's view 'it is no business of the state or ... of other individuals to try to make men moral; only an individual can do that for himself' as otherwise he would lose his autonomy. 20 He believed that each man was his own sovereign moral legislator as 'every man knows in his heart what is right and what is wrong'. ${ }^{21}$ If this is correct, then it follows that if a person chooses to break the law and he knows he is doing wrong, he is deserving of punishment. To what extent it is true that each man knows what is right and wrong is now more open to debate than it was in Kant's time. ${ }^{22}$ Furthermore, the extent to which a person appreciates that something is right or wrong may also have relevance to his responsibility and blameworthiness. Some choice theorists prefer the term 'defiance' to 'choice' suggesting that only those who consciously choose to act in defiance of legal norms deserve punishment. 23

Hart and Moore 24 are the two leading modern proponents of the 'choice' theory, although it has been suggested 25 that in extending 'choice' to include capacity and opportunity as necessary elements dilutes the focus on actual choice and their stance would be more appropriately labelled 'capacity theory'. The intention here is to use 'choice' to encompass both the original and extended versions. The basis of this theory is that an agent should not be punished unless he had both the capacity and a fair opportunity to abide by the law.26 An early reference to this theory 27 has been traced back to Blackstone ${ }^{28}$ who considered legal excuses were founded on:

the want or defect of will. An involuntary act, as it has no claim to merit, so neither can it induce any guilt: the concurrence of the will, when it has its choice either to do or avoid the act in question, being the only thing that renders human actions praiseworthy or culpable. 
The 'choice' theorists maintain that a person should only be held criminally liable for actions that he freely chooses to do. Therefore 'one is responsible if he could have done otherwise',29 could in this context meaning 'could have done otherwise if he had chosen to'. 30 This choice was not made impossible by external factors beyond the control of the agent. Surprisingly, Moore at one point excludes from the ambit of free-choice situations where a choice is also made 'very difficult' by such external factors, but this extension appears only once in his argument ${ }^{31}$ and whether it could include involuntary intoxication and cases such as Kingston ${ }^{32}$ is unclear.

\section{Mens rea and choice}

Accordingly, only intention and recklessness where the defendant foresaw a risk of harm and went on to take the risk of it would suffice as mens rea; negligence, for the majority of choice theorists, would not be sufficient. 33 Subjectivists follow this rationale maintaining that a lack of awareness of the risk of harm makes it impossible for $D$ to make a 'rational and voluntary choice' to act in a manner that risks breaking the law. 34 The other important principle for choice theorists is belief; a person should only be responsible for what he believed he was doing in the circumstances he believed to exist at the time rather than for what actually did happen or what the actual circumstances turned out to be. ${ }^{35}$ Any actions that fall outside of these principles should not attract criminal liability as a person cannot be responsible for matters of chance or luck 36 that are beyond his control.

Only chosen conduct, therefore, attracts responsibility and culpability so that even if a person's actions create an obvious risk of harm to others and that harm results, the person will not be liable unless he was aware of the risk himself. The advantage of this approach to culpability is that it recognises and respects individual autonomy. The citizen is able to exercise control over his own life knowing that he will only be liable to criminal sanctions if he chooses to break the law and he has the power to determine for himself whether or not to do so.

However, Hart ${ }^{37}$ managed to justify including negligence within choice theory by arguing that negligent behaviour could be encompassed where $\mathrm{D}$ had the capacity to act like a reasonable person. He believed that D would be culpable where he possessed both the physical and moral capacity to abide by the law and had a fair opportunity to avoid criminal behaviour. 38 This sophisticated and complex version of choice theory overlaps substantially with character theory by including moral incapacity.

Others would refute the suggestion that a person can in any real sense 'choose' to behave in a negligent manner 39 as negligence connotes inadvertent action and if no thought is being given before acting in a particular way how can the subsequent act be 'chosen'? 40 If criminal liability should only lie where $D$ is both responsible and culpable, this arises only where $D$ has control which is limited to those things he chooses to do or causes to happen. This subjective view limits the influence of chance and luck that should be irrelevant to criminal liability. ${ }^{41}$ It is submitted that a person can in a sense 'choose' to behave negligently in that he can choose not to do a risk assessment before he acts. It is acknowledged that there is merit in the argument that usually one does not truly 'choose' to be inadvertent, but if we agree that we can control our actions then we must accept that we can choose to take care to avoid harming others.

Hampton 42 acknowledges difficulty in reconciling choice or defiance theory with negligence as it is implausible to argue that an inadvertent person has chosen to defy the law, but she lapses into character theory (discussed below) when she justifies criminal liability for negligence by proposing that the act of defiance arises not at the time of the actus reus of the offence but much earlier in the process of that person's character formation, i.e. he developed an irresponsible character in defiance of what he knew to be an acceptable standard of responsibility. 43 The problems with this proposal are that it fails to consider the many instances where responsible people behave negligently because of momentary lapses in concentration and it also fails because of the assumption that people can choose their characters and the dispositions they want to possess. 44 Moreover, even where someone has opted to become a careless person, it would not necessarily mean that on a particular occasion when they had acted carelessly it was as a consequence of their chosen disposition. However, on a traditional Kantian view, liability for negligence would only lie where $\mathrm{D}$ had an opportunity to become aware of the risk. 
Moore, an original supporter of Hart's accommodation of negligence within choice theory, now rejects his approach on the basis that it shifts the touchstone of responsibility from choice to capacity ... relegating choice to a subsidiary role'. 45 This is because giving capacity such prominence would mean that there were two ways responsibility could be grounded based upon the agent's capacity: he could choose to do wrong or be inadvertent. Moore argues that 'what makes the intentional or reckless wrongdoer so culpable is not unexercised capacity' but his choice not to exercise it. 46 Horder questions the inclusion of the word 'so' before 'culpable' querying whether Moore is saying that choosing not to exercise this capacity grounds culpability or whether such a choice makes $D$ more culpable than he would be if he had not made such a choice and had simply been careless. 47 Furthermore, he sees Moore's criticism of Hart's approach to negligence as an inconsistency in Moore's own argument because 'the moral capacity to avoid wrongdoing, which ... Moore regards as an essential prerequisite for a culpability judgment, is the very basis ...' of liability for negligence as Hart realised. 48

\section{The meaning of 'choice'}

As 'choice' underpins culpability it is necessary to determine what 'choice' actually means. It could be said that where a person acts under duress, for example, or while suffering from a mental disorder, he is still making a choice to engage in prohibited conduct. Should such conduct attract culpability? Choice theorists would argue that making a choice requires the exercise of 'free will' and thus someone acting under duress would be exculpated as the expression of free will is absent in such circumstances. This concept of 'free will' needs to consist of 'the capacity for choice ... and of choice as a rational capacity which manifests our freedom as responsible agents'. ${ }^{49}$ If this approach is taken the mentally disordered offender is appropriately exculpated if he lacked such rational capacity at the time he did the act.

Where the agent is acting under duress, it is difficult to assess to what extent $D$ is not exercising his free will. Certainly, $D$ is making a choice in one sense as he could refuse to give in to the threats. It may be preferable to view him as freely acting in a manner in which he would not normally do. It is not an involuntary action, just a choice to act in a way that is inconsistent with D's normal behaviour because of circumstances beyond his control. The difficulty with linking choice to normal behaviour is that it encroaches on the second theory of culpability, character theory, discussed below.

Hart did not examine what attributes D would need in order to be capable of behaving in a reasonable manner, but such an account was propounded by Moore who stated that $D$ would need:

those qualities of character that we think persons should possess, and those capacities of mind that we think all persons do possess ... He is ... capable of calculating what actions are likely to lead to what results and even to assign relative probabilities to each. $\mathrm{He}$ is, in other words, a pre-eminent practical reasoner, finding the morally and legally correct major premises ... and forming the accurate means/end beliefs ... for his minor premises ... It is because people have the capacity to reason this way that they can be said to be culpable when they do not do so. 50

The next question is what makes choices impossible or difficult? Hart provides the answer, 'either an incapacity in the agent' (an internal factor of the agent) 'or the lack of fair opportunity to use a non-defective capacity' 51 (an external factor, the situation the agent finds himself in).

Perhaps in circumstances where $D$ is acting under duress the justification for excusing D's actions under choice theory is not founded on the argument that $D$ did not choose to break the law, but rather that he chose to break the law because he lacked a 'fair opportunity' to do otherwise. Moore examines the 'fair opportunity' excuse rather than a capacity-based defence in his discussion of a hypothetical duress problem where $D$ is under duress because he is threatened that if he wants to prevent something good happening to someone he hates he must take part in a robbery. Most choice theorists would reject an 'internal disability' capacity-based excuse like hatred because 'recognizing fears, cravings, instinctual desires, strong passions, or other internal states as excuses unduly reduces one's true responsibility'. 52

Moore previously considered that someone motivated by hatred to act under duress could be held morally 
accountable because 'moral agents choose to act "out of character" all the time' and although the hatred of the victim would predispose $D$ to give in and act he still retained the power to choose to act differently. ${ }^{53} \mathrm{D}$ 's 'fair opportunity' excuse would also be rejected as, although his choice was harder than it would be for others who did not hate $\mathrm{V}$, he still had a fair opportunity to act otherwise. For a claim of lack of a 'fair opportunity' to succeed there 'must be some (objectively regarded) evil that one is avoiding'. 54 Our opportunities 'are not unfairly diminished simply because they are diminished ... [F]air opportunity is not measured by ...

psychological difficulties, but rather by the objective facts of the matter'. ${ }^{5}$ It is only where $D$ acts to prevent a substantial harm that the diminished opportunity defence will operate. It is not relevant that subjectively the choice may be hard.

If this view is followed, it is submitted that the defendant in Kingston 56 would be correctly convicted and the suggestion 57 that perhaps a 'destabilisation' defence could apply in such circumstances would not find favour, even though the possibility of the creation of a new defence would have been acceptable to some members of the judiciary in the Court of Appeal and the House of Lords in this case. 58

Moore's requirement that opportunity be measured by objective fact could allow us to make a 'character-based moral judgment' about D's failure to act in a morally responsible manner. 59 He has now recognised that defining the 'moral self' purely in terms of conscious will is too narrow and that 'some' emotions must be considered. 60

Moore is criticised for failing to address the implications of broadening his view of the moral self whilst still maintaining the capacity for rational choice as the sole determinant of moral culpability. Furthermore, 'it is not clear that we choose some of the strongest emotions that motivate our choices, nor is it clear that we can simply choose not to feel or act on the basis of such emotions'. 61 It may be accepted that our strongest emotions are not a matter of choice and that we might not be able to control what we feel on their basis but we can feel what we want as long as we do not necessarily act on those feelings. The criminal law provides a partial defence to murder where provocation is established 62 to recognise that although the conduct is wrong it is excusable to a degree because $D$ was justifiably provoked even though his act of killing could not be condoned. 63

\section{The role of luck or chance}

Are elements of luck or chance irrelevant to the choice theorist? It can be argued that although 'outcome' luck is irrelevant, 'constitutive' luck is relevant because it has resulted in me being the person that I am and influences the free choices that I make when I decide whether to engage in criminal conduct. 64 Furthermore, choice theorists assume that every individual is a rational moral agent, free to make his or her own choices, without addressing what attributes a person needs to become a fully developed moral agent and how such attributes are acquired. 65

One question that this point raises is the extent to which we have control over our 'constitutive' luck, if any? Some individuals may never develop into moral agents because of 'bad constitutive luck'. 66 Determinists would argue that we are what we are and we have no control at all, but if this is the case, it would be difficult justifying state punishment for any criminal offences because defendants simply could not help being what they are and acting the way they did--they were just unlucky to have been 'made that way'. 67 'Situational' luck is also relevant because it places me in a position where I can be exposed to temptation or have the opportunity to commit crime. ${ }^{68}$ Although this affords no excuse, it perhaps explains why people with previously good characters can suddenly act in a manner that is inconsistent with their previous conduct and it can be a mitigating factor in sentencing. Whether such uncharacteristic conduct can be said to be 'out of character' is an issue that will be discussed below. 69

However, the idea that an individual can control his own life and make conscious choices to abide by the law presupposes that the citizen is always aware of the law. In legal systems where ignorance of the law is no excuse it is difficult to argue that the citizen can always exercise a free choice to abide by the law, even though he is making a free choice in acting. Such a position of ignorance can arise in several different ways, including where it is hard for the citizen to discern what the law is in relation to a particular action or 
circumstance and also where a person has previously been accustomed to observing a different legal system with different cultural mores 70 and perhaps a different perception of what is morally right. ${ }^{71}$

\section{Flaws in the choice theorists' approach}

Although the choice and character theories are termed theories of excuses, they can also be seen as being inculpatory, i.e. as theories of culpability. One of the inherent flaws in the choice theory is its capacity to inculpate a person who would otherwise not be criminally liable in relation to criminal attempts. If criminal liability is rightly attached to those who intend to engage in criminal activity, then the person who attempts to commit a crime and fails should be punished in the same way as the person who completes the offence; there is no difference in culpability. ${ }^{72}$ Similarly, there are problems where a person believes that he is committing a criminal offence when in fact he is not. Using the example of a person recklessly starting a bonfire, aware that it might damage a neighbour's fence, a subjectivist would have to accept that this person would be equally subject to conviction if the fence was damaged, if the fence was actually not the neighbour's but the person's own fence, and even if the fence was not damaged at all. ${ }^{73}$ If a man is to be liable for what he intends or believes, this result is a natural consequence.

An even more disturbing consequence, it is submitted, is in relation to the defence of mistake. If the choice theory is accepted as the appropriate test for culpability, a person who believes that a woman is consenting to sex should be acquitted of rape as long as he can show that he honestly believed she was consenting. His belief does not have to be on reasonable grounds. ${ }^{74}$ Similarly, if $D$ mistakenly but genuinely believes he is about to be attacked and attacks an innocent person in 'self-defence', then under choice theory his belief would negate the mens rea for an offence under the Offences against the Person Act 1861. Alternatively, if he was justified in acting in self-defence, but used objectively 'unreasonable force', the defence, on the choice theorists' view, should still be available to him as long as he believed the force used was necessary. Under the current law the defence would fail.

Furthermore, self-induced intoxication also poses problems for choice theorists 75 as it is open to a defendant to argue that he was so drunk that he lacked the capacity to make an informed and rational choice and therefore should not be found culpable for acts committed whilst in this state. Intoxication removes inhibitions and can increase the risk of criminal behaviour. 76 Although it is possible to argue that the agent makes a free choice to drink earlier, prior to the actus reus of the offence, and the effects of intoxicants are well publicised, the law on self-induced intoxication still leaves us with two issues. The first issue is the obvious criticism that in founding liability on an earlier free choice there is not the usual coincidence of the actus reus and mens rea that is normally a prerequisite for liability. In these circumstances for public safety reasons, the intention to drink without regard to its possible effects is substituted for the relevant mens rea and the intent to drink is transferred to the commission of the offence. This is because being advertently reckless in becoming intoxicated can be morally equated with the fault element of subjective recklessness that is often sufficient for criminal liability. ${ }^{77}$ As Lord Mustill stated in Kingston, 78 (for a crime of basic intent) it is not possible to rely on an absence of mens rea when that is caused by D's voluntary acts. However, his Lordship's assertion that self-induced intoxication is a substitute for mens rea is not correct as it would not take into account the slightly intoxicated defendant whose defence would be that he would have acted in exactly the same way and with the identical state of mind if he had been completely sober, he would have still failed to see the risk of harm. 79

The second issue to consider is whether it would be appropriate to blame someone who had never been intoxicated through drugs or alcohol before and who would therefore have no idea of the effect of the intoxicants upon him. The circumstance envisaged here is where someone consumes a very small amount of an intoxicant but experiences an unusual reaction to it. It could be argued that such an individual is not making a free and rational choice, if he does not realise the effects the intoxicants will have upon him, being unaware of how the intoxicant will affect his personal capacity to make a rational choice.

One difficulty with the choice theorists' requirement of a fair opportunity is that the theory is ambiguous on this requirement as a failure to avoid wrongdoing can vary from a cognitive failure in the case of a negligent act to a failure to meet the standard of the reasonable man for the defence of duress. Such 'fundamental 
differences' between the two failures are 'hidden behind the all-embracing notion of "fair" or "unfair" opportunity'. 80 Moreover, the theory misses any consideration of the way harm is caused, a central feature of determining degrees of culpability. 81

\section{Moral agency and the capacity for moral responsiveness}

Perhaps the biggest flaw of all in the choice theory is that there is an insufficient account of what preconditions are necessary for an individual to make a free and rational choice. ${ }^{82}$ It fails to provide an 'adequate account of what it is to be a responsible agent, or of what makes an action "mine" as its responsible agent'. 83 The choice theorists' assumption that everyone is a moral agent is one of the major flaws in their theory because they have paid insufficient attention to two of the three fundamental conditions on which the theory is based. 84 Moral theorists generally agree that three requirements must be satisfied before moral blameworthiness can be attributed, namely: '(1) a moral agent (2) must breach some governing moral norm (3) under circumstances ... that give the moral agent a fair opportunity to avoid its breach'. 85 For Arenella, choice theorists fail to pay sufficient attention to the first and second of these prerequisites and they should explore the link between 'moral address and evaluation' and the 'special attributes' $D$ needs 'to understand and use moral norms as a reason for his action'. 86 These attributes have been identified as the 'abilities to react to moral norms in thought, feeling, perception and behaviour'. 87 Where these attributes are absent, or where D fails to 'exercise them competently', then it is necessary to determine whether D can control the aspects of his character that govern his capacity for moral responsiveness. In consequence only a 'character-based conception of a moral agent's necessary attributes can explain how this capacity for moral responsiveness is developed' and why it may sometimes be appropriate to blame those who fail to exercise it. 88

Both retributivism and utilitarianism rely on choice theory as the rationale for moral responsibility and the theory is also compatible with a 'soft determinist' view which assumes that sane adults are free to act in accordance with their reasoned choices, a limited autonomy as they cannot 'revise their will'. 89 Furthermore, on a 'hard determinist' view both choice and character theories would be rejected as both a person's actions and characters would be predetermined. However, for choice theory to be accepted, it needs to explore whether it is fair to hold someone morally accountable for the 'goals, desires, values, and emotions that motivate his rational choices'. 90 Choice theory would inculpate psychopaths and the brainwashed, and yet could exculpate those who would be currently liable, for example, negligent offenders and those unable to rely on a criminal defence because they failed to live up to the standard of the 'reasonable man. ${ }^{91}$

Focusing on psychopaths, Arenella finds two faults with the choice theorists' assertion that moral blameworthiness can be grounded where there is both capacity and opportunity to abide by the law, as it would equally apply where the law in question was morally neutral and also where it was morally bad when disobedience would be meritorious. Secondly, he challenges the 'assumption that the capacity to be moved by moral reasons for action is not a necessary condition of moral agency', 92 asking why a person should be deemed to be a moral agent if he 'lacks the capacity to deliberate about whether he should have acted differently'. 93 If we accept that such moral responsiveness is a precondition for criminal liability, this would raise several other issues including how such a capacity should be determined. Would it need to be determined in every case unless $D$ was either very young or insane? How should we deal with those found to be morally unresponsive, and should we distinguish between those who lacked the capacity and those who had capacity, but failed to exercise it competently?

Moore accepted that choice theorists did not demonstrate how the ability to be a practical reasoner could explain how a person developed moral responsiveness and his position has now altered. 94 Recognising this issue and focusing on the capacity element in his hypothetical duress problem, he questions whether the responsible self is to be identified solely in terms of conscious will or whether some emotions should be included. If emotions are included, then it is possible that character-based judgments are being incorporated.95 This second difficulty leads him to examine whether our emotions and our 'choosing agency, the will' are inextricably linked. 96 Although it is possible that our emotions need not necessarily control our choice processes, choice theorists must accept that some emotions have a role to play in the formation of our intentions and beliefs and in any plan of action, 'emotions are both products and causes of the 
judgements we make as we decide what to do', 97 but Moore submits that they are not 'invaders of our processes of reasoned deliberation'. 98

If it is accepted that emotions do not incapacitate choice, the effect on Moore's hypothetical duress problem would be that where someone is genuinely acting under duress out of fear for his own safety or that of others, he would only be able to rely upon the second limb of choice theory, diminished opportunity, which could not be correct when considered in the wider context of defences. ${ }^{99}$ This would be fatal for those claiming other defences such as provocation where the second limb is not available. Moore considers the psychological view that some emotions 'short circuit' choice and questions whether such emotions can ever continue without the choice to give them free reign, but he offers no answer to this conundrum. ${ }^{100}$

Moore stands accused of misunderstanding the nature of choice when he sees intentional and reckless wrongdoing as 'paradigm examples of chosen wrongdoing' because it 'presupposes a comparison between alternative courses of action' which may not occur. ${ }^{101}$ Often the intentional or reckless actor may act spontaneously without considering other options and as such Moore's analysis of the relationship between mens rea and culpability is flawed because it cannot accommodate those who act impulsively. They have made no choice and yet are still culpable. This point can also be extended to include the negligent actor who, as already discussed, is not really making a choice. When examining this issue it may also be worth considering the extent to which spontaneous and instinctive acts should be deemed to be 'reactions' rather than 'actions'.

When considering 'choice' from a 'defiance' stance 102 the grounding of criminal culpability lies in D's defiance of the law in causing harm, as $\mathrm{D}$ makes a choice to defy an authoritative moral command in order to satisfy personal desires, knowing obedience is expected. ${ }^{103}$ However, it is important to acknowledge that this is not the sole consideration. An example to illustrate this point is where D intentionally rapes or kills. In such cases, 'the nature of the harm and the way in which it is caused to the victim are naturally thought of as central to an explanation of culpability, ... not just a manifestation of defiance'. 104

\section{Character theory}

The main proponents of character theory are Aristotle, 105 Hume, 106 and more recently Bayles, 107 Pincoffs 108 and Arenella. ${ }^{109}$ The basis of founding criminal liability on character is appealing as it reflects a general communitarian principle that only 'bad people' should be punished. It is still a subjective theory because it founds culpability on the subjective character traits of the individual agent. For Hudson, '[m]oral virtues and vices ... are traits which received opinion holds to be traits of character; they are time-tested'. 110 Hume proposed that '[b]lame and punishment are not directly for acts but for character traits ...' and such traits are not restricted to ones which an individual can voluntarily control, as considered by Aristotle, but 'any socially desirable or undesirable disposition'. ${ }^{111}$ As such, criminal liability is properly grounded where D's action manifests an undesirable character trait that requires correction. If an act does not indicate an undesirable character trait, blame would be inappropriate yet preventative measures could still be taken to avoid future unwanted consequences. This could be the use of civil detention for the mentally disordered or perhaps education and training. Although the foremost of these preventative measures can be achieved by compulsion, without criminal liability it is difficult to see how individuals could be compelled to undertake education or training currently.

There is a certain attraction to the view that a person's actions are representative of their good or bad character, that people are 'moved to perform certain actions' 112 providing a 'motivational pattern' which might be strongly linked to desires and aversions. Traditional character theorists such as Plato, Aristotle and Brandt pay insufficient attention to the 'interrelationships between desires, emotions, the will and various competencies and abilities'. ${ }^{113}$ For Aristotle, a person should aspire to develop good character traits, which he terms human virtues or excellences, but such excellences are only achieved when certain conditions are satisfied. For an individual to possess a trait deemed to be a human excellence, an act apparently demonstrating such a trait is insufficient in itself. What is required is that the individual must be in the right state when he does them. 
First, he must know [that he is doing virtuous actions]; second, he must decide on them, and decide on them for themselves; and third, he must do them from a firm and unchanging state. 114

Such a human excellence could be acquired by habituation. Plato, Aristotle and Hume believed that character traits were linked to desires, and possession of a particular virtue or vice could motivate someone to act in a certain way. Following on from this, a direct link could be made between motivation and desires.115 Furthermore, both Plato and Aristotle 'thought that human excellences applied primarily to persons and only secondarily to actions' ${ }^{\prime 16}$ hence Aristotle's three preconditions noted in the quote above.

Character traits have been defined as 'relatively stable patterns of thought, emotion, and action ... dispositions to act in certain ways, to be motivated or affected by certain kinds of consideration, to think in certain ways'. 117 What the law demands of its citizens is 'certain dispositions: of obedience to its rules and of respect for the values it protects'118 which requires them to have or develop particular character traits which will enable them to be law-abiding members of society. Although it could be argued that it should not be within the ambit of the criminal law to interfere in the moral character of its citizens, character theorists can counter such arguments by restricting criminal liability only to undesirable moral character traits that are likely to lead to or produce obviously harmful conduct. Such harmful conduct is rightly the concern of the criminal law. This raises further questions, however. Condemning undesirable character traits that result in harm to others affirms the harm principle ${ }^{119}$ and could be justified on this basis, but what must be considered further is (1) whether it can be acceptable to punish an agent for a defective character trait before this trait has been manifested in harmful conduct, ${ }^{120}$ and (2) whether one harmful act alone can be shown to manifest such an undesirable character trait.

\section{The requirement of an act}

To address the first of these questions, it would generally be seen as unacceptable for the criminal law to extend its reach to punish its citizens for bad thoughts without such thoughts, indicative of an undesirable character trait, manifesting themselves in a harmful act. This is because it is a characteristic of human nature that people are all capable of bad thoughts but such thoughts usually do not lead to harmful conduct. Although there were government proposals to detain dangerous and severely personality disordered individuals under a new Mental Health Bill 121 if they were diagnosed as potentially posing a serious risk to themselves or others, but before they had committed any criminal offence, such proposals were not pursued. The Humean character theory could be seen to support the view that such preventative action is justified, but blameworthiness alone is an insufficient condition for punishment or treatment because granting the State the power to punish or treat without an overt act requirement 'unreasonably risks freedom for security'. ${ }^{122}$

The character theorist's answer to the second question also provides a rationale for the answer to the first question. Without an act there would be insufficient evidence of an undesirable character trait that deserved censure and a social response. If actual criminal conduct were not a requirement, there would be a danger that innocent people would be convicted. This approach establishes that the connection between the undesirable character trait and criminal conduct are contingent. To punish on the basis of what an individual would or might do rather than for actual deeds fails to respect the presumption that the individual is a rational and responsible agent. ${ }^{123}$ As yet it does not answer why one act can be sufficient to attract liability.

Character theorists propose that the courts should determine in each case whether one action was indeed sufficient to evidence an undesirably dangerous disposition and if it did not they should acquit. ${ }^{124}$ Also the criminal law's general requirement of proof of mens rea, for example that an act is done 'purposely, knowingly, recklessly ...' can help to support the inference of bad character. ${ }^{125}$ The different mental elements required by the mens rea of offences differentiate between attitudes to harm with greater blame being attached to more undesirable attitudes. However, on a Humean character view, liability for negligence could be difficult to justify as it may not be possible to infer an undesirable character trait from one careless act.

Lacey's view is that defendants should not be held criminally liable for 'out of character' actions, actions only being 'in character' when they are 'genuinely expressive of the agent's disposition'. ${ }^{126}$ An obvious response 
to this suggestion is that any theory which exempts liability for serious harm on the basis that the conduct was uncharacteristic of the defendant's normal disposition is clearly controversial. However, an alternative way of addressing these issues is to state that if the 'out of character' behaviour is a result of circumstances that would give rise to a defence then exemption for liability would be justified. This is because the agent's 'capacity to guide his actions by the values to which he was truly committed'127 was impaired.

\section{Character theory, Kingston, and acting 'out of character'}

This raises the question of how character theorists might deal with a case like Kingston. ${ }^{128}$ From the judgments it was found that the defendant retained some control over his actions and he knew that what he was doing was morally wrong. His argument that his capacity to retain his self-control was diminished by involuntary intoxication 129 attracted sympathy from the Court of Appeal, but the House of Lords held that a drugged intent was still an intent--the circumstances only affording mitigation. In the Court of Appeal, Lord Taylor of Gosforth was prepared to allow a defence where the sole reason for crossing the threshold between having paedophilic inclinations and putting them into practice 'is, or may have been that the inhibition which the law requires has been removed by the clandestine act of a third party', ${ }^{130}$ as 'the operative fault is not his'.

There are different ways of interpreting the character of the defendant in Kingston from these circumstances. The first possibility is that he was acting 'out of character' whilst he was denying his desires and that when he sexually assaulted the boy he was then acting in accordance with his character and should not be afforded any excuse. Alternatively, it could be argued that having previously managed successfully to control his predilections, the defendant had shown evidence of good character and this incident was an example of 'out of character' behaviour that should therefore be exculpatory. This second view would accord with the proposition that character theorists must acknowledge the interdependency between possession of a particular trait, D's strength or weakness of will and his choices. ${ }^{131}$

Sullivan observes that sexual preferences are a matter of luck and to require forbearance is 'to require a great deal'. ${ }^{132}$ Consequently, where someone becomes blamelessly disinhibited and loses self-control when tempted it is not obvious that it is in the public interest for him to be punished for a stigmatic offence ${ }^{133}$ unless his conduct was very grave, such as killing and non-consensual penetrative sex.

There are some, like Aristotle, who would dispute whether a person's character was all a matter of luck.

Persons who have attained sufficient maturity can, it is argued, by introspection and reflection respond to criticism and resolve the tension between first- and second-order desires. Values can be strengthened and secured, thereby developing and enlarging moral selves. ${ }^{134}$

However, to what extent such exercises can affect a person's ability to control his or her sexual preferences is open to debate. It has been suggested that in some circumstances criminal responsibility should be subject to a 'unity of self doctrine' so that in cases such as Kingston, where there is a 'temporary change in the mentality or personality' 135 of $D$ as a result of blameless external factors which arise outside D's control, a defence should be possible. ${ }^{136}$ Lord Mustill admitted that there 'is an instinctive attraction in the proposition that a retributory system of justice should not visit penal consequences on acts which are the ultimate consequence of an event outside the volition of the actor'137 and that to treat it as purely a matter of mitigation was unjust.

\section{A destabilisation defence}

A form of character theory could be employed in cases where $D$ is blamelessly destabilised by exceptional circumstances to such an extent that he acts in a way that he would not otherwise have done. This would apply to a first, or first relevant, offence and would require consideration of previous convictions, if any, before a defence of 'good character' could be raised. ${ }^{138}$ In other words, 'good character' for the purposes of this proposal simply means an 'absence of previous relevant convictions or relevant character-based 
acquittals'. 139 In the few exceptional cases where such a defence could be raised, as it would not be available for the most heinous wrongdoing, ${ }^{140}$ punishment could not be justified on either Kantian or utilitarian grounds. For retributivists, punishing those whose crimes were committed as a result of circumstances that were not of their own making and where compliance with the law was made extremely difficult for them is to 'punish beyond just deserts, notwithstanding the presence of mens rea and the absence of compulsion', ${ }^{141}$ and from a utilitarian viewpoint deterrence would not be achievable because of the requirement for exceptional circumstances.

Horder 142 has called for recognition of destabilisation in extending the scope of the diminished responsibility defence to other criminal offences and under these proposals the success of the defence leaves $D$ under the authority of the court so that, where appropriate, treatment or custodial measures could be imposed. However, Sullivan observes that the class of persons put forward for his own destabilisation defence would cause considerable forensic difficulties in determining whether or not those persons met Horder's conditions, given their volitional and cognitive resources. ${ }^{143}$ Tadros $^{144}$ is supportive of Sullivan's defence in cases of involuntary intoxication. However, he submits that such a defence should be extended to apply to situations where $D$ gets into the relevant state but is justified in getting into that state. Consequently, excuses should be 'sensitive to shifts in character but only if there are acceptable reasons for those shifts'. On such a basis, the defence of provocation would be founded upon the recognition that $D$ was justified in getting angry in the circumstances.

More recently the Law Commission rejected any move towards a defence of 'reduced inhibitions or blurred perception of morality' 145 in cases of involuntary intoxication. The Law Commission could not agree to support Sullivan's proposal to negative mens rea completely where D was still to some extent at fault, as with the partial defence of provocation. Apart from public safety demands, it drew attention, as Lord Mustill had already noted, to practical difficulties with any such defence, including the fact that it would be an entirely subjective test ${ }^{146}$ as to whether a particular defendant's inhibitions or 'moral compass' were completely undermined, a factor that would be difficult for a jury to determine even with the aid of expert evidence. Furthermore, there was concern that the 'strength of D's disposition to engage in anti-social conduct should not make it easier for $D$ to claim a complete excuse for any crime committed in consequence'. 147

Finally, if such a defence was permitted where D's inhibitions were caused by an act for which he was blameless, there would be no grounds for refusing to recognise 'a general character-based excusatory defence for any inherent condition or "irresistible impulse" for which D is equally not responsible'.148 However, the Law Commissioners considered that extending existing defences ${ }^{149}$ to give them a more general application could be argued for, but was beyond the scope of their current deliberations.

\section{A broader view of character traits and acting 'out of character'}

Arenella adopts a 'motivational' view of character traits which goes beyond the descriptive view that stems from identifying a person's 'consistent course of action over time', and takes a more 'holistic and integrated' view of character which 'referred to the way an individual's relatively consistent and coherent values, emotions, desires and aversions interact with each other over time to generate that person's goals, motivations, and interpretations of his social reality'. 150 If we apply the first limited conception of character, then any act inconsistent with the normal pattern of behaviour will be 'out of character', whereas if we adopt his second broader view, fewer actions will be judged to be 'out of character' even when a person has never acted in such a way before. This is because understanding a person's character allows us to identify enduring moral character traits in his future actions.

Criminal actions are constitutive of the kinds of character traits and dispositions that should concern the criminal law and therefore the actions must be 'suitably related to the attitudes or motives which are aspects of her continuing identity as a person'. These are 'the agent's practical attitudes as manifested in and constituted by her criminal actions'. ${ }^{151}$ Any 'out of character' behaviour in the relevant sense is neither indicative of the agent's settled dispositions nor does it reveal 'character' at all. Finding criminal actions as constitutive of undesirable character traits supports the view that the law should treat citizens as rational and responsible agents and seek to guide their conduct by giving them good reasons to comply with its 
requirements. On this basis it is necessary to subject them to criminal sanctions only where they refuse to act rationally by complying with legal requirements when they have the capacity to do so.

\section{Character theory and the mentally disordered}

The mentally disordered offender could pose a problem for some character theorists. It has been suggested that it would be appropriate to convict a criminal with a severe mental disorder because his behaviour demonstrates an undesirable character trait ${ }^{152}$ and whether he lacked the capacity to conform to the law is irrelevant. However, it is conceded that treatment rather than punishment could be more appropriate if it could correct the undesirable trait. Presumably if treatment would not be effective that would leave punishment as the only option on such a view. This notion has been rejected on the basis that it abandons 'any attempt to justify a "character" theory of criminal liability: it destroys the distinction ... between condemning and punishing responsible wrong-doers for their crimes, and diagnosing and treating those who are dangerous to themselves or others'. $153 \mathrm{~A}$ more rational response to the problem of mentally disordered offenders is for the character theorist to recognise that 'defects of character are defects of attitude or motivation' and a mental disorder does not fall within such a definition:

[Character] consists in a person's rational dispositions of thought, feeling, and motivation--those which reflect an intelligible conception of reality and value. It is, though, a defining feature of mental disorder that it involves non-rational, or rationally unintelligible, patterns of thought, feeling, and motivation. ${ }^{154}$

As the mentally disordered individual is incapable of engaging in a critical discussion of his conduct or his underlying motives for acting, such a person cannot be held morally responsible or criminally liable as this is reserved only for rational agents. This proposition would also seem to suggest that the individual needs to possess the capacity for reflection. Although this argument is persuasive, it must be remembered that the term 'mental disorder' covers a multitude of states of mind, ${ }^{155}$ for example ranging from psychopathy to depression, and whereas a severely mentally disordered agent might well be incapable of rational thought, it does not follow that all mentally disordered individuals are so afflicted. ${ }^{156}$ On that basis it is suggested that this proposition needs to be refined somewhat to exclude from liability those who are genuinely incapable, but to hold accountable those who have sufficient capacity. This would obviously require expert medical evidence to be adduced in each case. 157

\section{Character theory and capacity for moral responsiveness}

Arenella, who extends character traits to include 'motivational character traits', 158 agrees that a capacity for reflection is necessary, but does not restrict his discussion to this capacity alone. He proposes that moral agents need a 'capacity for moral responsiveness' which presupposes an appreciation of the 'normative significance of the moral norms governing their behavior' coupled with an assumption that they can 'exercise moral judgment' to apply these norms appropriately. This latter ability requires 'moral motivation: the desire to use the applicable moral norm as the basis for acting' which can be acted upon 'despite conflicting desires and impulses'. ${ }^{159}$ In summary, these factors are crystallised down to 'some modest capacity for critical self-reflection and self-revision'. 160 These moral capacities are acquired and developed through social interaction and the ability for character control 'often requires some form of socially created transformational opportunity being made available to an individual who has the capacity to take advantage of it'. ${ }^{161}$ Therefore, where defendants have experienced life conditions that have made it difficult for them to develop into full moral agents, we need to address these conditions and offer the individuals transformational opportunities. Aristotle himself considered that the importance of a 'good upbringing' was essential to the development of a good character ${ }^{162}$ and the rejection of bad character traits.

To what extent are we responsible for our characters? ${ }^{163}$ There are the opposing opinions of Robert Owen164 who believed that a man's character is formed independently of himself and Aristotle's view that people can be rightly blamed for having acquired a bad character if they have failed to live how they should and have been negligent in developing their character. ${ }^{165}$ However, Aristotle did not advocate punishment for bad character alone, rather that possessing a bad character could not be available as an excuse for 
breaking the law. A common misconception of Aristotle's view is that in firmly believing that everyone had the capacity to develop human excellences, he did not accept that if a person lacked such a capacity he could be excused for his bad actions. Such actions themselves were sufficient to ground culpability. ${ }^{166}$ In support of this stance, where incapacity to abide by the law is attributable to some negligence on the agent's part in striving to develop a stronger and better character, he should not be excused from his wrongdoing. There should be a presumption that our characters are our own responsibilities. ${ }^{167}$

Pincoffs describes character traits as largely a 'subclass of personality traits' which are 'generally approved or disapproved' by society focusing on 'moral character traits which we have a moral right to demand or expect of one another'. 168 Such character dispositions are then subdivided into two separate categories, determinate and determinable dispositions and he argues that both are needed for a just society.

Determinate dispositions are ones that can be enshrined in law and tell us precisely what we must or must not do to qualify as having the disposition, the examples given are 'you must not steal' or be 'incestuous'. 169 However, determinable dispositions, such as fairness, honesty and concern for others need to be cultivated too. But the converse of these determinable dispositions, e.g. unfairness, dishonesty, indifference to others, can be manifested in so many different ways that if we have the right to expect that individuals should cultivate their characters so that they develop good determinable dispositions we have a problem. How are such good dispositions cultivated, and is everyone in possession of an innate ability to cultivate them or is it something that can be acquired?

The example of fairness is used to illustrate how difficult it would be to explain what we mean if we want people to be fair. Even with an interminably long set of instructions which could be followed, the 'individual might still be blindly following the instructions ... without any sense that what he is doing is right or wrong because [sic] fair or unfair. The sense of fairness is essential; it is this that we have a right to demand'. ${ }^{170}$ But can we demand a sense of fairness from an agent who may be incapable of meeting such a demand? This raises questions about how a sense of fairness develops in an individual and to what extent the individual would have control over its development. If these positive attributes are not automatically developed and an individual has not been helped to develop them, by having good role models, experience, education, religious moral instruction, to what extent can we blame agents for acting immorally? ${ }^{171}$

Arenella examines this issue from another perspective in his criticism of choice theory, questioning whether it is appropriate to hold an agent to be blameworthy when he cannot appreciate the moral significance of legal norms on the sole basis that he has the capacity to comply with the law for non-moral reasons. 172 If an agent is incapable of empathy and views 'moral norms as arbitrary restraints' on his autonomy should he be morally blameworthy where he makes a purely rational choice and commits an offence? This question can be addressed by arguing that many theorists have blurred the distinction between legal and moral norms; breaching the criminal law does not necessarily involve moral fault. Furthermore, an individual needs certain attributes to 'understand and use moral norms as a reason for his action' and where an individual lacks 'such attributes or fails to exercise them competently' we should determine whether the individual had control over the character aspects that impair his capacity to conform before finding blameworthiness. ${ }^{173}$

Choice theorists would argue that simply having the capacity to make a choice to abide by the law would be sufficient to ground culpability, but it must at least be recognised that the majority of citizens have moral as well as legal reasons for conforming, making it easier for them to be law abiding. Where it is more difficult for an individual to comply with the law because of a lack of moral development should allowances be made? Choice theory is inadequate here on the basis that it defines 'the moral agent's capacities for rational and uncompelled action in the abstract without tying those capacities to the unique character of the individual possessing them'. ${ }^{174}$ In consequence, most criminal defendants can be held morally blameworthy without consideration of the factors that may have impacted upon their ability to conform because they are capable of rational self-determined action. This would only exempt young children and the insane from culpability unless defendants could rely on an excuse of 'lack of a fair opportunity' to act otherwise. Even then, in cases like Kingston, ${ }^{175}$ being judged to have retained some control would be fatal to a defence.

It could be said that morally we can demand desirable character traits from members of our community because they are demands that are universal for the common good. To fail to criticise those who fail to live up to our universal standard is to encourage 'characterological free enterprise' but by finding fault 'the 
element of justice enters in'. 176 Moreover, as questions of fairness are moral and an agent is less inhibited without a well-developed moral character, no one should be permitted an unfair advantage over others by being allowed to build the wrong kind of character. ${ }^{177}$ It is submitted that to criticise and to condemn bad acts is appropriate but that justice does not necessarily demand punishment or the stigma of a criminal conviction, which can be viewed as a punishment in its own right.

However, character theorists recognise that character formation is not attributable to one thing or one person alone, 'being a matter of circumstances and of degree'. 178 Many things impact on a person's character formation, including genetics, family, environment, circumstances, accidents, experience, etc. On this basis, it has been argued that where there is sufficient reason to believe that the agent 'could not have helped becoming what he has become', and his defects of personality are correctable, then he should be treated. This treatment would be to help the agent behave to an appropriately acceptable standard that he can 'understand and accept for good reason'. 179 Presumably, where such an agent has a notably uncorrectable defect or one that does not respond to treatment in a particular case punishment would be the only option, on utilitarian grounds. If an agent could have avoided becoming what he has become, then Pincoffs advocates punishment. ${ }^{180}$ It is submitted that proving that someone could have done something to avoid becoming what he has become may be very difficult.

\section{Character theory and attempts}

When considering the law of attempts, a character theory of liability can readily justify criminalising attempts as demonstrating an undesirable character trait, which would be the basis for equal punishment whether the attempt was successful or not. Only the agent's voluntary withdrawal from his course of action before a crime was committed would 'block' the inference of a bad character trait. ${ }^{181}$ This would justify a defence of 'abandonment' whereby a person could rebut an inference of bad character from some acts made towards the commission of an offence by proving a 'voluntary and sincere renunciation' of his actions. 182

The character theory works well in the area of impossible attempts. If you try to steal something which is actually your own property, then it is appropriate to be convicted of attempted theft. However, there is a difference in the implications of the 'character' theory and those of the 'choice' theory in relation to radically inept attempts. Although such an inept attempt reveals an undesirable character trait, 'criminal liability requires more than "mere blameworthiness": that defective disposition must be dangerous, likely to lead to actually harmful conduct' and so the probable impact of the individual on society must be assessed. ${ }^{183}$ Even if undesirable character traits are evident, punishment (and presumably treatment) would only be justified where the trait is likely to produce criminal harm. Taking the example of someone sticking pins in dolls, 'should the person be disposed to change methods in light of the ineffectiveness of his current one', ${ }^{184}$ it is then that the criminal law would rightly have an impact.

This approach, although linked with the harm principle, raises questions about how much leeway should be given to a person with a bad character trait once he is seen as potentially capable of criminally harmful conduct. It is an ethical dilemma that has no perfect solution. On the one hand, the criminal law is there to protect society, but, on the other hand, we require a criminal act before the State can intervene. ${ }^{185}$ If an undesirable character trait is manifested in criminal conduct, and that character trait is treatable, then treatment rather than punishment would be more appropriate. However, if treatment could be provided at a stage before the commission of the criminally harmful conduct, then such conduct could possibly be prevented.

\section{Flaws in the character theorists approach}

One major criticism advanced by 'choice' theorists would be the exclusion of criminal liability where the agent acted 'out of character'. 186 The assertion that culpability is grounded on bad character traits which are attributable to the 'settled disposition of the agent' is seen as a major error ${ }^{187}$ on the part of some character theorists like Lacey. 188 This is mainly because it would exculpate even the gravest harm intentionally inflicted if $D$ acted uncharacteristically. Rather than seek a settled disposition or trait, character theorists 
should instead hold that the crux of culpability lies in an 'evaluation of the defendant's conduct, in the circumstances, in the light of an idealised conception of an agent of good character'. ${ }^{189}$ Accordingly, liability could then arise even where $D$ has previously been of scrupulous character.

Of course, although this suggestion is a logical means of solving this issue for some character theorists, it would need to incorporate some elements of the capacity/choice theory to accommodate those who lack the capacity to attain the minimum reasonable standard set by this idealised 'good character'. Without such an accommodation this view links well with Gardner's ${ }^{190}$ proposal, discussed below, ${ }^{191}$ that culpability is determined in light of a person's ability to fulfil his or her particular role in the way a reasonable person in that role should.

Moore, the leading critic of character theory, has scrutinised the character theorists' position on the relationship between character and actions and concludes that it means:

... we are excused from responsibility for our actions when those actions do not manifest, express, reveal or indicate bad character; when such actions are not the result of, not determined by, explained by, or are not attributed to bad characters; when such actions are not an exercise of a character defect; or when such actions are not evidentiary of bad character. ${ }^{192}$

\section{Character and action}

Moore first questions whether responsibility for character is merely a retrospective analysis of past behaviour because if character amounts to nothing more than this it is clearly wrong: 'character is not identical to past behaviour although it can be evidenced by it'. 193 Nor can he accept that character can be determined by dispositions to act in certain ways in the future. He rejects the notion that the character theorists' stance noted above describes the logical relation between character and actions that are 'in character' on the basis that it is 'too behavioural'. ${ }^{194}$ Considering whether a causal link exists between character and action would move away from a purely behavioural focus but this would be problematic too because character traits can be manifested in a variety of ways and not just one. He gives the example of the greedy man who can either demonstrate greedy behaviour or can behave in an overtly generous way in an effort to compensate for his greediness. ${ }^{195}$

\section{The 'out of character' problem}

Whether an overtly generous person could genuinely be greedy is open to question. An obvious difficulty that arises once an action is labelled as 'out of character' and therefore subject to exculpation would be in ensuring that it was not the result of a latent character defect that was manifesting itself at a suitable opportunity or arising because of a change in external circumstances. How can we know whether someone is a person of reasonable firmness, for example, if they have never been put to the test? An apparently honest and trustworthy person may suddenly decide to steal when an opportunity to take an unusually large amount of money presents itself for the first time or when he realises he is in a lot of debt and face a greater temptation than before. It is difficult to insist that such cases would be examples of 'out of character' behaviour. It is such concerns that have prompted challenges to the traditional restricted view of character theorists and to submit that there are crucial connections between possession of a character trait and how such a trait links in with both the motivational goals and desires, and the strength of will of the individual. ${ }^{196}$

Having rejected the behavioural approach and the causal link discussed above, Moore argues that an 'evidentiary relation' between character and action is the most appropriate approach:

Some act $A$ will evidence some trait $C$ if and only if not only $C$ causes $A$, but also states of type $C$ typically cause events of type A. Effects are evidence of causes only where there is some general connection between the class of events that includes the effect and the class of events that includes the cause. 197

Moore uses this 'evidentiary relation' to try to identify a distinction between a person's character and his 
choices to differentiate between the two leading theories of culpability. He concludes that the character is not just another way of referring to choice as:

[a]ny action evidences the possession of a will, because a will can typically will anything and still be a will. But ... while a character can cause any action, to be possessed of a character precludes the possibility that one's character can typically cause any class of actions equally well. Characters, to be characters, can only typically cause some classes of actions, but not others. ${ }^{198}$

At first sight this argument seems to be correct because otherwise how would any class of action be indicative of a character trait? The difficulty lies with Moore's own example of the character Bulstrode. ${ }^{199}$ If a greedy person can hide his greedy disposition by being overtly generous to others then surely to be 'possessed of a character' does not preclude acting contrary to it if we so wish.

The criminal actions that the character theorist would excuse for being 'out of character' are precisely the same kind of actions that the 'choice' theorists would exclude on the basis that that they were not 'freely chosen'.200 There are similar problems for the character theorist with the defence of mistake as there are with the 'choice' theory, namely that as long as the mistake blocks any inference of a bad character trait it should be irrelevant that the mistaken belief is unreasonable. The only way character theorists could catch the unreasonable mistake-maker would be if there was a lesser offence of negligence as to make an unreasonable mistake could be sufficient to infer the undesirable character trait of failing to take reasonable care.

\section{What is 'character'?}

The next question is how broadly should 'character' be defined? Drawing on the work of Freud and Watson, Moore examines how we constitute our sense of self 'through owning up to, or disowning various emotions, desires or behaviors. The phenomenological sense of the id is of the "not-me", the ego-alien emotions, thoughts etc.'201 that we may suppress into our subconscious. Freud's view was that the ego-alien represents our 'instinctual desires and emotions' and Watson proposed that our sense of self exists in the 'reflective, evaluative self that picks and chooses which of the desires, emotions, thoughts, etc. are worth being considered part of the self'.202

If this research into the phenomenology of character is accepted, does character include only the part of us that we identify as 'self' or the broader view encompassing other elements like our instinctual desires? If the broader view of character and choosing are taken, then both choice and character theorists can equally ground culpability where D states that his wrongful action stems from strong emotions. ${ }^{203}$ It would also be arguable that if the broader view of character is adopted it would be difficult if not impossible to suggest that D's action was out of character. Plato referred to this as the appetite or spirited part of us and St Paul called this the sin that has its lodgings in us' (Romans 7: 14-20) which subsumes/overrides the part of us that directs moral action. 204 For Hampton, when this has occurred it would be unfair to punish as we do not choose the part of us that is the 'bad part' that overrides the 'good part' of us when we act immorally. Yet this argument cannot prevail because in the majority of instances we do possess the capacity to control our instincts and desires even though we may choose to give in to them knowing that we are doing wrong. 205

It has also been suggested that if a person knowingly acts immorally and is 'genuinely indifferent to the authority of moral imperatives', then such imperatives do not apply to that person, 'she is outside their scope and hence does nothing wrong', such a person is 'amoral' rather than immoral and moral blame would be unjustified. 206 However, just because someone is 'indifferent' to moral imperatives does not necessarily mean that they do not apply to them. If such a person is incapable of moral responsiveness, then perhaps such an attempt at excusing them is correct. Alternatively, if someone has this capacity but simply chooses to pursue their own desires in the full knowledge that they are breaching society's moral norms, then blame is fully justified.

\section{To what extent are we responsible for our characters?}


If 'character' is simply another way of describing our 'choosing agency', there is really only one theory, choice, 207 unless there is a 'metaphysical difference between character and will'. Whilst not denying that in some sense we are responsible for our characters there is 'room for disagreement as to exactly how and in what sense'. 208 There are two possibilities as to how we could be deemed responsible: the first is that we have chosen to become what we are, but if this is correct, it collapses into choice as its foundation; the second option is that we are responsible for our characters because 'we are (at least in part) our characters'.209 For Moore, although Aristotle advanced the first view, there are two reasons to doubt it. The first is whether we actually have much of a capacity to mould our characters; and then perhaps more fundamentally, 'who is the "he" who is choosing character? Does he himself have any character, and, if so, was it chosen too?'210 This is a problem for character theorists, which 'invites an infinite regress'.

Must a person already possess some character before he can start this selection process to build the character he wants to become? Do we acquire some through early experiences and then at some point afterwards start to make choices? Moore addresses such questions using what he terms the weak Aristotelian view--initial character formation is something we have little or no control over, responsibility comes from 'our later choices to maintain these already formed traits'. ${ }^{11}$ Although he accepts there is some merit in this argument, he does not believe that it can account for all our attributes that can be subject to moral judgement, giving emotions as an example. Although we cannot will our emotions 'into or out of being', despite this 'we still hold people responsible for their emotional makeup'. 212 It is submitted that although we may hold people morally responsible for their emotional makeup, we expect people to control any morally reprehensible emotions and not act on them. It is only when they fail to exercise reasonable control and commit a proscribed wrong that we hold them criminally responsible.

Because of this problem Moore believes that it is the second possibility that reflects responsibility for character--'that we are, in part, constituted by our characters'. ${ }^{213}$ As such, although we do not choose to become or remain who we are in the same way that we choose and are responsible for acting in a certain way, responsibility for characters stems from 'a kind of aesthetic morality that governs our assessment of character' as character judgments have 'moral overtones' and we shun and disadvantage those with bad characters. 214 However, to 'the extent that such persons did not choose their character, they are ... morally unlucky'.215

\section{Moore's consideration of five claims made by character theorists}

The first claim, that preventative aims of punishment can only be justified when individuals have shown a bad character because others are not dangerous and punishment could not act as a deterrent, is dismissed by Moore because it cannot show when someone is morally innocent. The second claim, that character theory fits in well with the current practice in American law, he rejects because it does not show which theory the law should recognise. The third claim is that character theory can cope with the hard determinist view, difficult for choice theorists, if we support the argument that we are responsible for our characters 'because we are our characters'. ${ }^{216}$ The fourth is that character theory best represents society's blaming practices as it focuses on a more holistic view of the sort of person $D$ is, whereas choice theory is limited to an examination of capacity and opportunity at the moment $D$ acts. Moore argues that this still fails to explain why one theory is better than the other. ${ }^{217}$ The final claim for character theorists that Moore raises is Fletcher's view that 'an inference from the wrongful act to the actor's character is essential to a retributive theory of punishment'. As punishment is linked to desert 'the desert of the offender is gauged by his character' so that 'judgment about character is essential to the just distribution of punishment'.218

It is Lacey's defence of this stance that Moore then attacks. He examines her claim that it is morally 'unfair to hold people responsible for actions which are out of character ... [but] ... fair to hold them so for actions in which their central dispositions are centrally expressed'. ${ }^{219}$ He then tests this rationale by devising the following two examples:

(1) an actor freely chooses to do wrong (i.e., he had the capacity and a fair opportunity not to so choose), and yet the action is 'out of character' for that actor; (2) an actor's behavior is good evidence for a settled disposition (character) of a bad kind, and yet he has not (yet) chosen to act on that disposition.220 
If Lacey is right, Moore argues, we ought to find it fair to punish the second but not the first. Such a result would be obviously wrong. The problem with 'out of character' excuses, as in the first example, has already been discussed earlier. In relation to (2), if we examine Lacey's claim more closely, she is clearly requiring a wrongful act and not punishment for bad character per se. Also, if an actor's behaviour is truly to be taken as evidence of his bad character, are we to assume his lack of action in line with his bad character is simply down to a lack of opportunity to do so, or is it in the alternative, evidence of a good character in trying successfully to resist acting wrongfully?

Moore also takes issue with Lacey for whom 'bad character' means 'a settled hostility to, rejection of, or indifference to the values of the community that the criminal law seeks to protect and foster'. ${ }^{221}$ It is not clear why, for some character theorists, bad character traits require proof of a continuing bad attitude 222 but this is not the concern here. He quotes her statement that the criminal law should 'treat seriously the individuality and sense of identity of each person by responding punitively only to actions which are genuinely expressive of the actor's relevant disposition: with which the agent truly identifies, and can call her own'.223 On his interpretation this means that 'we are only our character' which has two 'startling implications'. The first is that as our character develops and changes we would become a different person; the second, that a multiple-personalitied person would actually be 'many persons with one character each'224 rather than just one individual. In consequence he dismisses the notion that character is equivalent to identity.

Although he may have a point here, perhaps all Lacey is suggesting is that before punishment can be justified, both a person's character and his identity need to be taken into account. Our characters show the 'kind of person' we are but our identity also encompasses 'who we are' and gives an insight into how we have become the person we are now. This would incorporate the weak Aristotelian view, as our identity would include factors such as our socio-economic background, education, IQ/capacity and our ability to be morally responsive, etc., and, in consequence, if $D$ could not have helped becoming what he has become, then punishment for crime is perhaps only appropriate where serious harm has been caused.

Moore admits that we have an 'aesthetic' kind of responsibility for 'unchosen' aspects of our character, but such aspects do not warrant punishment because 'we could not have avoided possessing these aspects of ourselves'. Consequently, choice theory is the preferred theory of excuse because it only 'excuses where there is no choice, no matter how much bad character may be exhibited' and does not 'excuse where there is free choice, however much out of character it may be'.225

A choice theorist would argue that the criminal law does not punish people for having a 'bad character' but it does punish those with 'good characters' who act in a bad way, thus choice theory is the correct blaming practice. However, the choice theorists' suggestion that only those showing objectionable character traits can be punished if character theory is employed could be rejected as negligent behaviour can also be encompassed either because D was 'careless and inattentive' as a person or because D failed to 'exercise [his] character strengths because of a momentary distraction'.226 Although it may seem appropriate to hold someone to be criminally liable for harm caused in circumstances where an individual is 'careless and inattentive' because they are indifferent to the welfare of those around them, it is hard to justify criminal responsibility where someone has been momentarily distracted simply because it can happen to us all.

Choice theorists struggle with liability for negligence but have argued that character theorists have difficulty too, which is a weak argument for promoting the supremacy of choice theory. ${ }^{227}$ Even though we may punish one negligent act such an isolated action does not signify that we are often careless, a bad character trait. When Lacey suggests that a consistently negligent actor demonstrates an attitude of indifference 228 this is not necessarily the case for all those who would fit this description, which could equally be attributable to 'awkwardness and stupidity'. ${ }^{229}$ In conclusion, Moore proposes that criminal liability for negligence can only be justified on utilitarian rather than moral grounds, as it cannot be founded upon culpable choice or culpable character unless it could be universally applied to all negligent actors. Similarly, character theory fails because it too cannot always apply universally even though it often can identify inferences of bad character where moral excuse fails. 230

\section{Is either theory a sufficient basis for criminal liability?}


None of the above theories of culpability can sufficiently or adequately explain the criminal law's determination of culpability to the exclusion of all other theories, possibly because it is as much the product of the 'shared history of cultural-moral evolution', 231 as it is of moral theory. ${ }^{232}$ It is also clear from the discussion above that there is a fair amount of congruence between them, each to some extent relying on the other.

The 'character' theory advances the preferred approach as to who can be held criminally liable, i.e. moral agents who exhibit anti-social and undesirable character traits, reminding us that actions can be judged as criminally wrong because of the bad attitudes that they reveal, as well as bad choices that have been made. However, the 'character' approach suggests that offenders are liable for what they are rather than for what they do.233 The 'choice' theory, on the other hand, identifies in a preferred way what we should be liable for, but it does this by reference to our 'choices' and fails to accept the integral relationship between our character and our choices. As Duff states, 'what the law is interested in is the character of our actions', not in 'character' as distinct from action. 234 It is clear that ignoring the link between character and choice weakens the choice theorists' stance and results in a failure of that theory to justify moral culpability. ${ }^{235}$ Neither theory sits happily with negligence, and both theories have difficulty with spontaneous and instinctive reactions where on the one hand there is no choice and on the other, there is no evidence of 'bad' character.

\section{'Agency' theory}

A third possibility has been proposed--'agency' theory236--where what is being judged is not 'character' but 'conduct ... by reference to its relative (lack of) success'. 237 This theory links better with degrees of mens rea and allows us to rank harms. Starting with the paradigm of successful agency, i.e. when harm is intentionally caused in the way intended, an evaluation of D's conduct depends on how close it comes to hitting this target directly, like the target in archery. An attempt to cause the same harm that was unsuccessful would form a concentric circle close to the circle of the paradigm as would intentional harm not caused in the intended way. Concentric circles further away from the centre would include endangerment and the 'lower the risk of harm posed by the particular conduct, the further distance' away it would be. 238 This would leave negligence the outermost ring. In this manner 'the way in which the victim is harmed, or subjected to the risk of harm, shapes culpability'. 239

However, even 'agency' theory cannot stand alone as it relies on the presumption that 'agency' means 'sane, mature agency' and it is thus dependent on capacity or character theory to justify the exculpation of the young and the insane. 240 With its focus on the way harm is brought about it disregards D's reasons for acting which are important when seeking to rely on the defence of duress, for example, and would again need supplementing by one of the other theories. This theory also fails to address the situation where the resultant harm exceeds that envisaged by the defendant, for example the one-throw punch that kills. Such circumstances can still be encompassed by the choice theory on the basis that $D$ chose to cause some harm, and to the character theory because it shows aggression.

\section{The 'role' theory of culpability}

Gardner 241 dismisses the traditional views of both choice and character theorists, judging them both to be flawed, and instead grounds culpability and responsibility on a role basis. In his rejection of character theory, he argues that the actions of $D$ are not merely evidence of D's character but rather constitute it. Therefore if $D$ acts 'out of character' it can only be a mitigating factor. Similarly he opposes choice theory which he finds inextricably linked to character theory:

the capacity that $\mathrm{D}$ has to act virtuously at $\mathrm{t}$ is also no more and no less than the virtue that $\mathrm{D}$ has at time $t$. And this is because one cannot have the capacity associated with a particular virtue whilst at the same time lacking the tendency to be virtuous. 242

However, possession of a good character trait is not equivalent to always behaving virtuously in accordance with it. Rather, our behaviour at any given time will be determined not only by whether or not we possess a 
particular virtue but also on our other 'motivations and goals'. 243 This view seems to support the proposition that strength of will and other goals are important. 244 Even if Gardner accepted a distinction between character and choice theories he would still find no ground for exculpation because a 'lack of capacity to behave with a good character provides no excuse at all'.245 Surely the question here does not concern a lack of capacity to behave virtuously, rather a lack of the strength of will to do so?

On Gardner's model, 246 responsibility only lies where we are fulfilling a role, for example a specific role such as doctor, police officer, teacher, parent or a non-specific role, i.e. a human being, and we fall below an idealised standard of a reasonable person in the role we are fulfilling. All roles have standards of character, skills and knowledge attached to them and $D$ should only be excused if his conduct fell within the boundaries of reasonableness for someone in that role. It is irrelevant whether we have the capacity to achieve this idealised standard; a person's capacity to do better is immaterial. Thus Gardner supports a stricter, more Aristotelian view of character theory. Yet currently the criminal law does acknowledge either a lack of responsibility or alternatively, for exculpation on capacity grounds, for example in defences like insanity and diminished responsibility, in relation to status as in infancy, and in cases such as $R v$ Sheppard.247

Gardner's proposal does not have universal application because it cannot adequately accommodate the defences of provocation, duress and involuntary intoxication, even though the first two incorporate elements of reasonableness. 248 Provocation becomes difficult because even if getting angry was justified it can never be reasonable to kill. In involuntary intoxication there is no standard of the reasonably intoxicated man for comparative purposes. This would not help a defendant like Kingston, and furthermore such a person could only be compared with a reasonable human being, not a person with Kingston's predilections. To allow adequately for these three defences, we need to rely on character and choice theories instead. This is because some part of our character is dependent on the reasons that motivate us and the reasons we are indifferent to, and following Sullivan's destabilisation defence proposal, this could affect D's ability to reason practically, to control himself, or 'an alteration in his motivations ... the reasons that motivate his actions'. 249

Accordingly, the defences of provocation and involuntary intoxication can only properly be grounded, not on Gardner's rationale, but on the basis that D's loss of control shows that he is no longer responsive to the guiding reasons that normally motivate him to act or refrain from acting, an argument founded in character theory. Alternatively, on a capacity view, $\mathrm{D}$ is exculpated because he could not have behaved any better than he did in the circumstances. Using duress as an example, where $D$ is overwhelmed by fear and submits to the threat Gardner would state that D's claim to be cowardly would not be a reason for excusing him of any wrongdoing but an admission of fault on D's part. In rebutting Gardner's claim that there is no distinction between D's character and the character of D's action at time $t$, D can possess a virtue without mechanically acting in accordance with it on every occasion. 250

In the Aristotelian tradition, Gardner 251 would state that if $D$ is courageous he would see life through the courageous person's eyes, viewing danger as a challenge and not as the threat that more cowardly people would perceive it to be. In consequence, $D$ cannot have the virtue of courage if he does not act courageously or if he has to overcome the inclination to act as a coward. Such a viewpoint would leave no room for the true hero, i.e. D who foresees the threat and may well be afraid but chooses to act courageously nonetheless. It could be argued that such an actor is truly courageous whereas Gardner's courageous person is one who may be acting without courage, acting impulsively perhaps. Courage suggests bravery--can $\mathrm{D}$ be brave if he only sees the danger as a challenge rather than a threat? This aside, being courageous surely depends upon the circumstances and whether the reasons to act or refrain from acting are sufficiently strong in that instance.

Using capacity theory, $\mathrm{D}$ could be allowed a defence even where he would fail to meet the standard of the reasonable person for the defence of duress because he is overly fearful. This would not be applicable where D's conduct showed a lack of respect for the criminal law, but this would make it necessary to be able to distinguish between a defendant who 'simply succumbs to fear'252 and the person who could not possibly have acted in any other way because of his fear. This would not be an easy distinction to make. A defence of choice theory in this regard seems to follow Hampton's 253 defiance theory principles, discussed above.

In contrast with the view that the criminal law is concerned with judgments about D's fitness for a particular 
role, for Tadros it is also concerned with D's manifestation of certain vices, those that cause $D$ to be 'insufficiently motivated to act or not to act by the interests of others'. 254 Carelessness should only be included where $D$ demonstrates insufficient regard for the risk that $D$ 's activity might cause to others to take proper care, particularly where the activity is a risky one. Any vices which do not show a lack of regard for the interests of others should not be the concern of the criminal law and 'merely having a vice, or displaying a lack of skill does not show this in itself'. 255 This view is held because criminal liability represents the State's condemnation which is only appropriate where D's vices cause harm and demonstrate a lack of concern for the interests of others. Where D lacks capacity these criteria are not met.

\section{Culpability and mens rea}

In Kingston, 256 Lord Mustill stated that mens rea is purely a technical term which specifies the mental element of the particular offence. 257 His Lordship found that the Court of Appeal's decision had been founded on the assumption that 'if blame is absent the necessary mens rea must also be absent',258 but that no such general principle exists in the criminal law. In Sullivan's analysis of Kingston, he notes Lord Mustill's view was that 'conviction for a serious offence need not entail descriptively or prescriptively that the defendant was in any sense at fault'. 259 Sullivan strongly opposes such a view as 'a conviction for a stigmatic offence is a sanction in its own right and that sanctions should only be confined to the blameworthy',260 limited only where there are issues of consistency and forensic practicability. Certainly Lord Mustill's view seems to conflict with that of Lord Bingham of Cornhill who said in $R v G$ and $R^{261}$ that conviction for a serious crime required proof of a culpable state of mind and that the problem could not simply be solved by conviction and a nominal penalty.

Neither of the two leading culpability theories can adequately link to mens rea. In relation to choice theory, there is nothing to explain the relevance of how harm was caused in determining the degree of culpability, and where 'mens rea issues are concerned, the character theory seems superfluous to an explanation of culpability'.262

So what is the relationship between mens rea and culpability? It would appear from the above that degrees of mens rea do not equate necessarily to the level of culpability, rather mens rea is only one facet to determining blameworthiness. Culpability is also influenced by other factors that feature in the criminal justice system which include the degree of harm caused, how the harm was brought about, the identity of the $\operatorname{victim}(\mathrm{s})$, whether it was a first offence, the capacity of the defendant and other mitigating circumstances. Such factors are relevant to sentencing rather than establishing that $D$ is criminally liable. Moreover, there are procedural matters such as the burden of proof, admissibility of evidence, etc. that cause practical difficulties in the trial process, factors that played a crucial role in the Commission's deliberations when deciding not to recommend a change to the law on involuntary intoxication. Culpability principles or mens rea must be sensitive to such procedural issues whereas moral culpability distinctions need not be. 263

Moral blameworthiness is more apparent in the defences that the criminal law permits and Fletcher's categorisation of defences into either justifications or excuses represents guidance as to the morality of behaviour expected. ${ }^{264}$ For example, where $\mathrm{D}$ has committed a proscribed wrong but can avail himself of the defence of self-defence, his behaviour would be justified in that he had done what was morally acceptable. Where $D$ has committed a proscribed wrong and is merely excused, for example where $D$ relies on the defence of provocation on a murder charge, then the message to society is that this kind of behaviour is not morally acceptable but some allowance is being made because of the circumstances $D$ was in. ${ }^{265}$ Consequently, the criminal law encourages citizens to develop reasonable standards of behaviour and is not simply reflecting expected standards. 266

\section{Conclusion}

It is apparent that there is no single theory of culpability or excuse that can universally apply to all circumstances. 267 Our choices, character and the role we are fulfilling are all relevant factors in determining 
criminal liability, but they are not an exhaustive list of considerations. Furthermore, it is not simply a matter of establishing culpability in these terms but of proving that $D$ had the mental element proscribed by the particular criminal offence with which he is charged.

Only character theory would seem able to support a defence for involuntarily intoxicated defendants like Kingston. With Sullivan's proposal a full defence would be available and Tadros would consider, at the very least, a partial excuse, either on the basis that his character had been destabilised or because his motivational reasons for acting or not acting had been altered by the intoxicants. As a result of the Law Commission's position, it would appear that in difficult cases like this, justice, even where there is conviction for a stigmatic offence, will be sacrificed on the altar of the greater good.

1 I am grateful to my colleagues Mike Bowen and Helen Howard for comments on a draft of this article. Any errors remain my own.

2 [1995] 2 AC 355.

3 A. Ashworth, 'Is the Criminal Law a Lost Cause' (2000) 116 LQR 225.

4 Gardner makes the point that such offences govern our specific activities in relation to the roles we assume, such as motorist, parent, shopkeeper, etc.: J. Gardner, Offences and Defences Selected Essays in the Philosophy of Criminal Law (Oxford University Press: Oxford, 2007) ch. 6.

5 G. R. Sullivan notes that in R v Kingston [1995] 2 AC 355, Lord Mustill's view was that 'conviction for a serious offence need not entail descriptively or prescriptively that the defendant was in any sense at fault', in 'Making Excuses' in A. P. Simester and A. T. H. Smith (eds), Harm \& Culpability (Clarendon Press: Oxford, 1996) 134.

6 P. Arenella, 'Character, Choice and Moral Agency: the Relevance of Character to Our Moral Culpability Judgments' (1990) 7 Social Philosophy and Policy 59 at 63.

7 M. D. Bayles, 'Character, Purpose, and Criminal Responsibility' (1982) 1 Law and Philosophy 5.

8 J. Bentham, An Introduction to the Principles of Morals and Legislation (Hafner: New York, 1948).

9 I. Kant, The Metaphysical Elements of Justice: Part 1 of the Metaphysics of Morals (Bobbs-Merrill: Indianapolis, 1965).

10 D. Hume, Treatise of Human Nature, L. A. Selby-Bigge (ed.) (Clarendon Press: Oxford, 1888).

11 For example Bayles, above n. 6 at 5.

12 Kant, above n. 8 at xi.

13 Bayles, above n. 6 at 5.

14 Kant, above n. 8 at 101.

15 Bayles, above n. 6, who attributes character theory to David Hume's Treatise of Human Nature, above n. 9.

16 Wilson credits the origin of character theory to Aristotle: W. Wilson, Central Issues in Criminal Theory (Hart Publishing: Oxford, 2002) ch. 11. 
17 'Only the law of retribution (jus talionis) can determine exactly the kind and degree of punishment', applying the 'retributive principle of returning like for like': Kant, above n. 8 at 101.

18 R. A. Duff, Criminal Attempts (Clarendon Press: Oxford, 1996) ch. 6.

19 Ibid. at 148 .

20 Kant, above n. 8 at $\mathrm{x}$.

21 lbid. at xi.

22 See, e.g., Arenella's discussion on the capacity for moral responsiveness as a prerequisite for criminal liability, discussed below.

23 J. Hampton, 'Mens Rea' (1990) 7 Social Philosophy and Policy 1.

24 M. S. Moore, 'Choice, Character, and Excuse' (1990) 7 Social Philosophy and Policy 29, where Moore notes that what he calls 'choice theory' has also been given other labels, including the 'capacity conception of responsibility' by Nicola Lacey (State Punishment (Routledge: London, 1988) 62); 'the responsibility principle' by Hyman Gross ( $A$ Theory of Criminal Justice (Oxford University Press: New York, 1979) 137); the 'Kantian theory of Responsibility' by Michael Bayles ('Choice, Character, and Excuse' (1982) 11 Law and Philosophy 5 at 6); and his own earlier label, the 'disturbed practical reason' theory of excuse (M. S. Moore, 'Causation and Excuse' 73 Cal L Rev 1091 (1985) at 1148-9 and Law and Psychiatry: Rethinking the Relationship (Cambridge University Press: Cambridge, 1984) 85-90).

27 See Moore, 'Choice, Character, and Excuse', above n. 23 at 32.

28 Sir William Blackstone, Commentaries on the Laws of England, Chitty (ed.), vol. IV (London, 1826) 20.

29 See Moore, 'Choice, Character, and Excuse', above n. 23 at 34.

$30 \quad$ lbid. at 35.

31 Ibid.

32 [1995] 2 AC 355. In this case, the defendant had been given drinks laced with drugs and video recorded indecently assaulting a 15-year-old boy. He raised the defence of involuntary intoxication. See further below.

33 See Duff, above n. 17 at 149.

34 See Arenella, above n. 5 at 70.

35 Such a principle appears to be reflected in the definition of recklessness found in the Draft Criminal Code for England and Wales, cl. 18(c) of the Criminal Code Bill (1989).

36 See Duff, above n. 17 at ch. 6. 
37 H. L. A. Hart, 'Negligence, Mens Rea and Criminal Responsibility' in Punishment and Responsibility Essays in the Philosophy of Law, above n. 25 at 136-57.

38 Ibid.

39 See Moore, 'Choice, Character, and Excuse', above n. 23 at 56.

40 See Duff, above n. 17 at 149.

41 Ibid. at $147-9$.

42 Above n. 22 at 27.

43 Ibid. at 27.

44 Horder, above n. 24 at 197.

45 Moore, 'Choice, Character, and Excuse', above n. 23 at 57.

$46 \quad$ Ibid. at 57.

47 Above n. 24 at 199.

48 lbid. at 200.

49 See Duff, above n. 17 at 150.

50 M. S. Moore, Law and Psychiatry: Rethinking the Relationship (Cambridge University Press: Cambridge, 1984) cited in Arenella, above n. 5 at 70 .

51 Hart, above n. 25 at 35.

52 Ibid. at 37.

53 Arenella, above n. 5 at 78.

54 Ibid., and see Moore, 'Choice, Character, and Excuse', above n. 23 at 37.

55 Moore, 'Choice, Character, and Excuse', above n. 23 at 40.

56 [1994] QB 81, CA; [1995] 2 AC 355, HL.

57 See Sullivan, above n. 4 at 145.

58 [1994] QB 81, CA, per Lord Taylor of Gosforth; [1995] 2 AC 355, HL; Lord Mustill at 375-8 could see serious practical difficulties with the recognition of a new defence and suggested the Law Commission's examination of intoxication should be enlarged to consider the questions raised by this appeal. 
61 Arenella, above n. 5 at 81.

62 Homicide Act 1957, s. 3; see now Coroners and Justice Act 2009, ss 54-56.

63 V. Tadros, 'The Characters of Excuse' (2001) OJLS 495; E. Colvin, 'Exculpatory Defences in Criminal Law' (1990) 10 OJLS 381.

64 Duff, above n. 17, ch. 6 .

65 See Arenella, above n. 5, and see discussion below under flaws in choice theory.

66 Ibid. at 69.

67 See Moore, 'Choice, Character, and Excuse', above n. 23 at 35.

68 See Duff, above n. 17 at 150.

69 Discussed below at n. 125.

70 M. Tunick, 'Can Culture Excuse Crime' (2004) 6(4) Punishment \& Society 395 at 396.

71 See Horder, above n. 24 at 214-15.

72 Duff cites Ashworth's example that there is 'no relevant moral difference' as far as their respective culpability is concerned between the would-be killer who succeeds and the one who fails; above n. 17 at 149 .

73 Ibid. at 172 .

74 DPP v Morgan [1976] AC 182 now overruled by Sexual Offences Act 2003, s. 1.

75 Also for those advocating a subjective approach to criminal liability, Law Commission, Intoxication and Criminal Liability, Cm 7526 (2009) paras 1.51-1.55; and see, e.g., Professor John Smith [1975] Crim LR 574.

76 Law Commission, above n. 74 at paras. 1.35 and 2.15.

77 Ibid. at paras 1.61 and 2.45 .

78 [1995] 2 AC 355 at 369.

79 See Law Commission, above n. 75 at paras 2.25-2.26.

80 Horder, above n. 24 at 203. 
81 Ibid. at 203.

82 Arenella, above n. 5 at 80; Duff, above n. 17 at 172.

83 Duff, above n. 17 at 176.

84 Arenella, above n. 5 at 60.

85 Ibid. at 60.

86 Ibid. at 61.

87 Ibid.

88 Ibid.

89 Ibid. at 64

90 Ibid.

91 Ibid. at 65.

92 Ibid. at 67.

93 Above n. 83 at 69.

94 Ibid. at 71.

95 Moore, 'Choice, Character, and Excuse', above n. 23 at 37.

$96 \quad$ lbid. at 38.

$97 \quad$ lbid. at 39.

98 Ibid. at 36.

99 Ibid. at 39.

100 Ibid.

101 See Horder, above n. 24 at 201.

102 See Hampton, above n. 22 at 1.

103 lbid. at 16. 
104

105

106

107

108

109

110

111

112

113

114

115

116

117

118 Ibid. at 177.

119 J. S. Mill, On Liberty (Penguin: Harmondsworth, 1974) ch. 1.

120 For example, a person suffering from a severe mental disorder, or someone with learning disabilities.

121 Home Office, Managing Dangerous People with Severe Personality Disorder, Proposals for policy development (July 1999); Department of Health and the Home Office, Reforming the Mental Health Act Part II: High risk patients, Cm 5016DII (December 2000).

122

123

124

125

126

See Horder, above n. 24 at 198

Aristotle, Nichomachean Ethics (trans. Terence Irwin) (Hackett Publishing: Indianapolis, 1985) Book III, ch. 5.

Hume, above n. 9.

Bayles, above n. 6 .

E. Pincoffs, 'Legal Responsibilty and Moral Character' [1973] 19 Wayne Law Review 905.

Arenella, above n. 5.

S. D. Hudson, 'Character Traits and Desires' (1980) 90 Ethics 539.

See Bayles, above n. 6 at 7

See Hudson, above n. 109 at 539.

Ibid. at 540 .

Above n. 104 at 1105 a 30.

See Hudson, above n. 109 at 539.

lbid. at 544-5.

Duff, above n. 17 at 177

Bayles, above n. 6 at 19

Duff, above n. 17 at 190.

Ibid. at 187 .

Bayles, above n. 6 at 8.

Duff, above n. 17 at 187. 
Ibid. at 188 .

128

[1994] QB 81, CA; [1995] 2 AC 355, HL.

129 There is a defence under the Model Penal Code if intoxication causes D to lack 'substantial' capacity to appreciate the criminality of his act 'or to conform his conduct to the requirements of law' (§ 2.08(4)).

$130 R$ v Kingston [1994] QB 81 at 89, per Lord Taylor.

131 Hudson, above n. 109

132 Sullivan, above n. 4 at 134.

133 Ibid.

134 Ibid. at 138

$135 R v$ Kingston [1995] 2 AC 355 at 365, per Lord Mustill.

136 Sullivan, above n. 4 at 137.

$137 R$ V Kingston [1995] 2 AC 355 at 363.

138 Sullivan, above n. 4 at 143.

139 Ibid. at 151.

140 Ibid. at 142 . Here Sullivan proposes the only relevance would be in mitigation.

141 lbid. at 141

142 J. Horder, 'Pleading Involuntary Lack of Capacity' [1993] CLJ 298.

143 Sullivan, above n. 4 at 150.

144 Tadros, above n. 62 at 497.

145 Law Commission, above n. 75 at para. 4.8 .

146 Ibid. at para. 4.19.

147 Ibid. at para. 4.20 .

148 Ibid. at para. 4.21.

149 Ibid. at para. 4.22; e.g. diminished responsibility, provocation or insanity. 
Above n. 152 at 180.

155 See White Paper, A Review of the Mental Health Act 1959, Cmnd 7320 (HMSO: 1976); Mental Health (Northern Ireland) Order 1986 (SI 1986 No. 595), art. 3(1); International Classification of Diseases (ICD-10) and Diagnostic and Statistical Manual (DSM-IV); and Green Paper, Reform of the Mental Health Act 1983 (DoH: 1999), which chose not to define 'mental disorder' but to leave it to the medical profession.

See, e.g. Re C (Adult: Refusal of Medical Treatment) [1994] 1 All ER 819.

157 Under the French Penal Code, Art. 64 provided that a person could not be guilty of a criminal offence if he was insane. This was interpreted by the judiciary to mean that the madder you were, the less guilty you were, see M. Foucault, Discipline and Punish: the Birth of the Prison (Allen Lane: London, 1977).

158 Arenella, above n. 5 at 81.

159 lbid. at 82.

160 Ibid.

161 Above n. 157.

162 Aristotle, above n. 104 at 1095a 25.

163 Pincoffs, above n. 107.

164 R. Owen, The Book of the New Moral World (1845) cited by Pincoffs, above n. 107 at 905.

165 See Pincoffs, above n. 107 at 906.

166 J. Gardner, 'The Gist of Excuses' (1998) 1 Buffalo Criminal Law Review 586.

167 See Pincoffs, above n. 107 at 906.

168 Ibid. Ibid. at 908-9.

170 Above n. 166 at 913.

171 Research by the Prince's Trust in 2008 showed that one in three teenagers did not view either parent as a good role 
model. This was attributed, in part, to the generation gap.

172 Arenella, above n. 5 at 59.

173 Ibid. at 60-1.

174 Above n. 171 at 64

175 [1995] 2 AC 355.

176 Pincoffs, above n. 107 at 917.

177 Ibid. at 920.

178 Ibid.

179 Ibid. at 923.

180 Ibid. at 922.

181 Duff, above n. 17 at 181.

182 Bayles, above n. 6 at 14

183 Duff, above n. 17 at 183.

184 Bayles, above n. 6 at 13.

185 See, e.g., the difficulty in the law of attempts when establishing whether the defendant has done something that is 'more than merely preparatory' towards the commission of an offence and the various tests employed to date and, particularly, the decisions in $R v$ Campbell [1991] Crim LR 268 and $R v$ Geddes [1996] Crim LR 894.

186 Duff, above n. 125.

187 Horder, above n. 24 at 207.

188 See Moore's criticism of Lacey on this point, below at n. 218.

189 Horder, above n. 24 at 207.

190 Above n. 3 and n. 165.

191 At n. 244 below.

192 Moore, 'Choice, Character and Excuse', above n. 23 at 47.

193 Ibid. at 41. 
194 lbid. at 47 .

195

196

197

198

199

200

201

202

204

205 For Aristotle this was a sign of 'incontinence' accordance with choice', above n. 104 at 1151a 1-7.

206

207

208

209

210

213

214

215

216 lbid. at 50 
Ibid.

218

219 1988) 77.

224 Criminal Liability (Blackwell: Oxford, 1990) ch. 5).

237

238

Ibid. at 51

See Horder, above n. 24 at 206.

Ibid. at 56 .

Arenella, above n. 5 at 75.

Horder, above n. 24.

Ibid.

Horder, above n. 24 at 215.

Ibid. at 193.

Duff, above n. 17 at 191.

lbid.

Arenella, above n. 5 at 61.

Horder, above n. 24 at 210.

Ibid. at 212.

Ibid at 51 quoting G. Fletcher, Rethinking Criminal Law (1978) 800.

Ibid. at 51 quoting N. Lacey, State Punishment (Routledge: London 1988) 8.

Above n. 206 at 53 citing N. Lacey, State Punishment (Routledge: London 1988) 189-90.

Moore, 'Choice, Character, and Excuse', above n. 23 at 53, quoting N. Lacey, State Punishment (Routledge: London

Moore, 'Choice, Character, and Excuse', above n. 23 at 54.

Moore, 'Choice, Character, and Excuse', above n. 23 at 58, citing N. Lacey, State Punishment (Routledge: London 1988)

Moore, 'Choice, Character, and Excuse', above n. 23 at 58.

Horder, above n. 24, who attributes the inspiration for this theory to the work of Antony Duff (Intention, Agency and 

Ibid. at 214

241 Gardner, above n. 3, and above n. 165.

242 Gardner, above n. 165 at 583.

243 Tadros, above n. 62.

244 Hudson, above n. 109 at 548 for his example of the Pliable Dodger who would normally act virtuously, but on one occasion does not because he lacks the strength of will; for Aristotle, such a person would be incontinent.

245

246

Tadros, above n. 62 at 496.

Gardner, above n. 165 at 593-6.

[1980] 3 All ER 899.

See Tadros, above n. 62 at 499-502.

lbid. at 504.

Ibid. at 496 and 502-3; and Gardner, above n. 165 at 583.

Gardner, above n. 165 at 582; and Tadros, above n. 62 at 511.

Tadros, above n. 62 at 514.

Hampton, above n. 22.

Tadros, above n. 62 at 517.

lbid. at 518 .

[1995] 2 AC 355.

C. Wells, 'Swatting the Subjectivist Bug' [1982] Crim LR 209 at 210.

$R v$ Kingston [1995] 2 AC 355 at 364.

Sullivan, above n. 4 at 135.

Ibid.

[2003] UKHL 50, [2003] 4 All ER 765. 
265 See Colvin's critique of the justification/excuse distinction in 'Exculpatory Defences in Criminal Law' (1990) 10 OJLS 381.

266 Gardner, above n. 165 at 594-5.

267 Tadros, above n. 62; Horder, above n. 24. 